\title{
HUBUNGAN PENERAPAN PP NOMOR 71 TAHUN 2010 DENGAN AKUNTABILITAS KINERJA LAPORAN KEUANGAN DAERAH PADA SEKRETARIAT DAERAH KOTA BENGKULU
}

\author{
Mulyadi \\ Ahmad Soleh \\ Program Studi Akuntansi \\ Fakultas Ekonomi Universitas Dehasen Bengkulu
}

\begin{abstract}
ABSTRAK
Mulyadi, Ahmad Soleh; Hubungan Penerapan PP Nomor 71 Tahun 2010 Dengan Akuntabilitas Kinerja Laporan Keuangan Daerah Pada Sekretariat Daerah Kota Bengkulu. Penelitian ini bertujuan untuk mengetahui pelaksanaan Peraturan Pemerintah Nomor 71 tahun 2010. Populasi dalam penelitian ini adalah pegawai Bagian Keuangan Sekretariat Daerah Kota Bengkulu, teknik pengambilan sampel yang digunakan berjumlah 15 orang dengan menggunakan metode sensus.. Hasil pengujian yang diperoleh menunjukkan bahwa terdapat hubungan antara Peraturan Pemerintah Nomor 71 tahun 2010 dengan akuntabilitas kinerja laporan keuangan daerah dan sisanya dipengaruhi oleh faktor lain yang tidak diteliti oleh penulis. Dengan demikian maka hipotesis penulis yang mengungkapkan bahwa PP Nomor 71 tahun 2010 berpengaruh terhadap akuntabilitas kinerja laporan keuangan daerah Sekretariat Daerah Kota Bengkulu terbukti.
\end{abstract}

\begin{abstract}
Mulyadi, Ahmad Soleh; The Relationship between the application of PP No 712010 With accountability performance of financial report at regional Secretariat in Bengkulu. This research aims to find out the execution of government regulation Number 71 in 2010. The population in this research is the member of Finance in regional Secretariat Bengkulu. It used census as the sample collection method by choosing 15 person as the sample. The test results show that there is a relationship between the regulation of the Government No. 71 in 2010 with the accountability performance of financial report at regional Secretariat in Bengkulu. while the others is affected by other factors which are not examined by the author. Thus the hypothesis that the authors reveal that PP Number 71 in 2010 affect the accountability performance of financial statements in regional Secretariat in Bengkulu is proved.
\end{abstract}

Kata kunci: Peraturan Pemerintah Nomor 71 tahun 2010, Akuntabilitas Kinerja Laporan Keuangan Daerah

\section{PENDAHULUAN}

Pengelolaan keuangan daerah merupakan salah satu bagian yang mengalami perubahan mendasar dengan ditetapkannya UU No. 32 tahun 2004 tentang Pemerintah Daerah dan UU No. 33 tahun 2004 tentang Perimbangan Keuangan antara Pemerintah Pusat dan Pemerintah Daerah. Kedua Undang-Undang tersebut telah memberikan kewenangan lebih luas kepada Pemerintah Daerah. Kewenangan dimaksud diantaranya adalah keleluasaan dalam mobilisasi sumber dana, menentukan arah, tujuan dan target penggunaan dana.

Di sisi lain tuntutan transparasi dalam sistem pemerintahan semakin meningkat pada era reformasi saat ini, tidak terkecuali transparasi dalam pengelolaan keuangan Pemerintah Daerah. Pemerintah Daerah diwajibkan menyusun laporan pertanggungjawaban yang 
menggunakan sistem akuntansi yang diatur oleh Pemerintah Pusat dalam bentuk UndangUndang dan Peraturan Pemerintah yang bersifat mengikat seluruh Pemerintah Daerah terdapat 2 (dua) subsistem, yaitu Satuan Kerja Pengelolaan Keuangan Daerah (SKPKD) dan Satuan Kerja Perangkat Daerah (SKPD). Laporan Keuangan SKPD merupakan sumber untuk menyusun Laporan Keuangan Pemerintah Daerah.

Peraturan Pemerintah Nomor 71 tahun 2010 tentang Pedoman akuntansi pemerintah merupakan revisi dari Peraturan Pemerintah Nomor 24 tahun 2005. Peraturan Pemerintah Nomor 71 tahun 2010 bertujuan untuk mengatur dalam penyajian dan pelaporan keuangan pemerintah. Denga adanya standar penyajian dan pelaopran keuangan pemerintah diharapkan laporan keuangan pemerintah dapat lebih dipahami, memiliki relevansi dan memiliki daya banding yang tinggi. Penerapan PP Nomor 71 tahun 2010 tentang Pedoman Standar Akuntansi pemerintah diwujudkan dalam bentuk laporan keuangan dengan tujuan menyediakan informasi untuk memenuhi kepentingan para pengguna laporan keuangan pemerintah. Laporan keuangan pemerintah terdiri dari laporan realisasi anggaran, laporan posisi keuangan (neraca), laporan arus kas dan catatan atas laporan keuangan.

Sebagai upaya kongkrit untuk mewujudkan transparansi dan akuntabilitas pengelolaan keuangan negara/daerah adalah penyampaian laporan pertanggungjawaban keuangan pemerintah yang memenuhi prinsip tepat waktu dan dapat diandalkan (reliable) serta disusun dengan mengikuti Standar Akuntansi Pemerintah (SAP) yang telah diterima secara umum. Satuan Kerja Perangkat Daerah (SKPD) merupakan bagian dari pemerintah daerah yang melaksanakan fungsi pemerintahan dan pelayanan publik, baik secara langsung ataupun tidak. Untuk melaksanakan tugas dan fungsinya tersebut, SKPD diberikan alokasi dana (anggaran). Oleh karena itu, kepala SKPD disebut juga Pengguna Anggaran (PA).

Sekretariat Daerah Kota Bengkulu merupakan bagian dari pemerintah daerah yang melaksanakan fungsi pemerintahan dan pelayanan publik, baik secara lansung ataupun tidak. Untuk melaksanakan tugas pokok dan fungsinya tersebut Sekretariat Daerah Kota Bengkulu diberikan alokasi dana (anggaran). Oleh karena itu, Sekretaris Daerah Kota Bengkulu disebut juga Pengguna Anggaran (PA).

Selaku Pemegang Kekuasaan Pengelolaan Keuangan Daerah (PKPKD), kepala daerah (Gubernur, Bupati, Walikota) yang mendelegasikan sebagian kewenangannya kepada kepala SKPD, pada akhirnya akan meminta kepala SKPD membuat pertanggungjawaban atas kewenangan yang dilaksanakannya. Bentuk pertanggungjawaban tersebut bukanlah SPJ (surat pertanggungjawaban), tetapi berupa laporan keuangan. Penyebutan SKPD selaku entitas akuntansi (accounting entity) pada dasarnya untuk menunjukkan bahwa SKPD melaksanakan proses akuntansi untuk menyusun laporan keuangan yang akan disampaikan kepada Gubernur/Bupati/Walikota melalui Pejabat Pengelola Keuangan Daerah sebagai bentuk pertanggungjawaban pengelolaan keuangan daerah. Kertas kerja/Laporan keuangan oleh SKPD ini dilatarbelakangi oleh Peraturan Pemerintah No. 71 Tahun 2010 tentang Pedoman Standar Akuntansi Pemerintah.

Sekretariat Pemerintah Daerah (Setda) sebagai salah satu Satuan Kerja Perangkat Sekretariat Daerah di wilayah Pemerintah Kota Bengkulu sekaligus sebagai pengguna anggaran juga harus membuat pertanggungjawaban atas kewenangan yang dilaksanakannya sesuai dengan Peraturan Pemerintah No. 71 Tahun 2010 tentang Pedoman Standar Akuntansi Pemerintah.

\section{TINJAUAN LITERATUR Pengelolaan Keuangan Daerah.}

Berdasarakan Undang-Undang No. 32 tahun 2004 tentang Pemerintah Daerah dan Undang-Undang No. 33 tahun 2004 tentang Perimbangan Keuangan antara Pemerintah Pusat dan Pemerintah Daerah merupakan satu kesatuan yang tidak dapat dipisahkan dalam upaya penyelenggaraan pemerintahan dan pelayanan masyarakat. Pada instansi yang relatif kecil dengan karyawan yang sedikit jumlahnya dan kegiatan operasi instansi masih misi utama 
kedua Undang-Undang tersebut bukan hanya keinginan untuk melimpahkan kewenangan pembiayaan dari Pemerintah Pusat ke Pemerintah Daerah, tetapi yang lebih penting adalah peningkatan efisiensi dan efektifitas pengelolaan sumber daya keuangan dalam rangka peningkatan kesejahteraan dan pelayanan kepada masyarakat. Semangat desentralisasi, demokratisasi, transparasi, dan akuntabilitas menjadi sangat dominan dalam mewarnai proses pengelolaan keuangan daerah pada khususnya. Untuk itu diperlukan suatu laporan keuangan yang handal dan dipercaya agar dapat menggambarkan sumber daya keuangan daerah berikut dengan analisis prestasi pengelolaan sumber daya keuangan daerah itu sendiri.

Menurut Peraturan Menteri Dalam Negeri No. 59 Tahun 2007 tentang Pedoman Pengelolaan Keuangan Daerah, keuangan daerah adalah semua hak dan kewajiban dalam rangka penyelenggaraan pemerintah daerah yang dapat dinilai dengan uang termasuk didalamnya segala bentuk kekayaan yang berhubungan dengan hak dan kewajiban daerah tersebut. Peraturan Menteri Dalam Negeri No. 59 Tahun 2007 tentang Pedoman Pengelolaan Keuangan Daerah, pengelolaan keuangan daerah adalah keseluruhan kegiatan yang meliputi perencanaan, pelaksanaan, penatausahaan, pelaporan, pertanggungjawaban dan pengawasan keuangan daerah. Terwujudnya pelaksanaan desentralisasi fiskal secara efektif dan efisien, salah satunya tergantung peda pengelolaan keuangan daerah.

Menurut Anissarahma (2008:36) Pengelolaan keuangan daerah adalah suatu proses pengendalian dan perencanaan pemerintah dalam memanfaatkan APBD untuk meningkatkan penilaian kinerja dan prestasi manajemen untuk mencapai tujuan jangka panjang dan jangka pendek.

Sesuai Peraturan Menteri Dalam Negeri No. 59 Tahun 2007 tentang Pedoman Pengelolaan Keuangan Daerah, pengelolaan keuangan daerah tak lagi bertumpu pada Bagian Keuangan Sekretariat Daerah (Setda) Pemerintah Provinsi, akan tetapi dalam Permendagri itupun disebutkan, setiap Satuan Perangkat Daerah (SKPD) wajib menyusun dan melaporkan posisi keuangannya, yang kemudian dikoordinasikan dengan bagian keuangan.

\section{Laporan Keuangan Daerah}

Laporan keuangan sektor publik merupakan komponen penting untuk menciptakan akuntabilitas sektor publik. Adanya tuntutan yang semakin besar terhadap pelaksanaan akuntabilitas publik menimbulkan implikasi bagi manajemen sektor publik untuk memberikan informasi kepada publik, salah satunya adalah informasi akuntansi yang berupa laporan keuangan.

Menurut Peraturan Pemerintah No.71 Tahun 2010 pada lampiran II paragraf 50, mengatakan Laporan Keuangan menyajikan secara lengkap informasi yang dibutuhkan oleh pengguna. Informasi yang dibutuhkan oleh pengguna laporan keuangan dapat ditempatkan pada lembar muka laporan keuangan atau catatan atas laporan keuangan.

Menurut PP RI No. 71 Tahun 2010 menyatakan laporan keuangan pokok terdiri dari:

a. Laporan Realisasi Anggaran

Menurut Peraturan Pemerintah No. 24 Tahun 2005, mengatakan Laporan realisasi anggaran menyajikan ikhtisar sumber, alokasi, dan pemakaian sumberdaya ekonomi yang dikelola oleh pemerintah pusat/daerah, yang menggambarkan perbandingan antara anggaran dan realisasinya dalam satu periode pelaporan.

Unsur yang dicakup secara langsung oleh laporan realisasi anggaran terdiri dari pendapatan, belanja, transfer, dan pembiayaan. Masing-masing unsur didefinisikan sebagai berikut:

1. Pendapatan (basis kas) adalah penerimaan oleh Bendahara Umum Negara/Bendahara Umum Daerah atau oleh entitas pemerintah lainnya yang menambah ekuitas dana lancar dalam periode tahun anggaran yang bersangkutan yang menjadi hak pemerintah, dan tidak perlu dibayar kembali oleh pemerintah.

2. Pendapatan (basis akrual) adalah hak pemerintah yang diakui sebagai penambah nilai kekayaan bersih. 
3. Belanja (basis kas) adalah semua pengeluaran oleh Bendahara Umum Negara/Bendahara Umum Daerah yang mengurangi ekuitas dana lancar dalam periode tahun anggaran bersangkutan yang tidak akan diperoleh pembayarannya kembali oleh pemerintah.

4. Belanja (basis akrual) adalah kewajiban pemerintah yang diakui sebagai pengurang nilai kekayaan bersih.

5. Transfer adalah penerimaan/pengeluaran uang dari suatu entitas pelaporan dari/kepada entitas pelaporan lain, termasuk dana perimbangan dan dana bagi hasil.

6. Pembiayaan (financing) adalah setiap penerimaan yang perlu dibayar kembali dan/atau pengeluaran yang akan diterima kembali, baik pada tahun anggaran bersangkutan maupun tahun-tahun anggaran berikutnya, yang dalam penganggaran pemerintah terutama dimaksudkan untuk menutup defisit atau memanfaatkan surplus anggaran.

7. Penerimaan pembiayaan antara lain dapat berasal dari pinjaman dan hasil divestasi. Pengeluaran pembiayaan antara lain digunakan untuk pembayaran kembali pokok pinjaman, pemberian pinjaman kepada entitas lain, dan penyertaan modal oleh pemerintah.

b. Neraca

Tujuan neraca adalah menyajikan informasi mengenai posisi keuangan daerah pada saat tertentu, biasanya pada akhir tahun anggaran. Posisi keuangan daerah adalah keadaan asset, kewajiban, dan ekuitas dana yang dimiliki pemerintah daerah pada akhir periode akuntansi.

Unsur yang dicakup oleh neraca terdiri dari asset, kewajiban, dan ekuitas dana. Masing-masing unsur didefinisikan sebagai berikut:

1. Asset adalah sumber daya ekonomi yang dikuasai dan/atau dimiliki oleh pemerintah sebagai akibat dari peristiwa masa lalu dan dari mana manfaat ekonomi dan/atau sosial di masa depan diharapkan dapat diperoleh, baik oleh pemerintah maupun masyarakat, serta dapat diukur dalam satuan uang, termasuk sumber daya nonkeuangan yang diperlukan untuk penyediaan jasa bagi masyarakat umum dan sumber-sumber daya yang dipelihara karena alasan sejarah dan budaya.

2. Kewajiban adalah utang yang timbul dari peristiwa masa lalu yang penyelesaiannya mengakibatkan aliran keluar sumber daya ekonomi pemerintah.

3. Ekuitas dana adalah kekayaan bersih pemerintah yang merupakan selisih antara aset dan kewajiban pemerintah.

c. Laporan Arus Kas

Tujuan laporan aliran kas adalah menyajikan informasi mengenai kemampuan dalam memperoleh kas dan menilai penggunaan kas untuk memenuhi kebutuhan daerah dalam suatu periode akuntansi.

Laporan aliran kas menggambarkan saldo awal, penerimaan, pengeluaran dan saldo akhir kas daerah dalam suatu periode akuntansi tahun berkenaan. Laporan aliran kas menyajikan informasi mengenai penerimaan dan pengeluaran kas yang berkaitan dengan aktifitas operasi, investasi dan pembiayaan.

Unsur yang dicakup dalam Laporan Aliran Kas terdiri dari penerimaan dan pengeluaran kas, yang masing-masing didefinisikan sebagai berikut:

1. Penerimaan kas adalah semua aliran kas yang masuk ke Bendahara Umum Negara/Daerah.

2. Pengeluaran kas adalah semua aliran kas yang keluar dari Bendahara Umum Negara/Daerah.

d. Catatan atas Laporan Keuangan

Catatan atas laporan keuangan meliputi penjelasan naratif atau rincian dari angka yang tertera dalam Laporan Realisasi Anggaran, Neraca, dan Laporan Arus Kas. Catatan atas Laporan Keuangan juga mencakup informasi tentang kebijakan akuntansi yang dipergunakan oleh entitas pelaporan dan informasi lain yang diharuskan dan dianjurkan untuk diungkapkan di dalam Standar Akuntansi Pemerintahan serta ungkapan-ungkapan 
yang diperlukan untuk menghasilkan penyajian laporan keuangan secara wajar. Catatan atas

laporan keuangan mengungkapkan hal-hal sebagai berikut:

1. Menyajikan informasi tentang kebijakan fiskal/keuangan ekonomi makro, pencapaian target Undang-undang APBN/Perda APBD, berikut kendala dan hambatan yang dihadapi dalam pencapaian target.

2. Menyajikan ikhtisar pencapaian kinerja keuangan selama tahun pelaporan.

3. Menyajikan informasi tentang dasar penyusunan laporan keuangan dan kebijakankebijakan akuntansi yang dipilih untuk diterapkan atas transaksi-transaksi dan kejadiankejadian penting lainnya.

4. Mengungkapkan informasi yang diharuskan oleh Standar Akuntansi Pemerintahan yang belum disajikan pada lembar muka laporan keuangan.

5. Mengungkapkan informasi untuk pos-pos aset dan kewajiban yang timbul sehubungan dengan penerapan basis akrual atas pendapatan dan belanja dan rekonsiliasinya dengan penerapan basis kas, dan

6. Menyediakan informasi tambahan yang diperlukan untuk penyajian yang wajar, yang tidak disajikan pada lembar muka laporan keuangan.

Karakteristik kualitatif laporan keuangan adalah ukuran-ukuran normative yang perlu diwujudkan dalam informasi akuntansi sehingga dapat memenuhi tujuannya. Menurut Peraturan Pemerintah RI No. 71 Tahun 2010 menyatakan ada empat karakteristik yang merupakan prasyarat normatif yang diperlukan agar laporan keuangan pemerintah dapat memenuhi kualitas yang dikehendaki:

a. Relevan

Laporan keuangan bisa dikatakan relevan apabila informasi yang termuat di dalamnya dapat mempengaruhi keputusan pengguna dengan membantu mereka mengevaluasi peristiwa masa lalu atau masa kini, dan memprediksi masa depan, serta menegaskan atau mengoreksi hasil evaluasi mereka di masa lalu. Dengan demikian, informasi laporan keuangan yang relevan dapat dihubungkan dengan maksud penggunaannya.

Adapun Informasi yang relevan adalah sebagai berikut:

1. Memiliki manfaat umpan balik (feedback value)

Informasi memungkinkan pengguna untuk menegaskan atau mengoreksi ekspektasi mereka di masa lalu.

2. Memiliki manfaat prediktif (prediktive value)

Informasi dapat membantu pengguna untuk memprediksi masa yang akan datang berdasarkan hasil masa lalu dan kejadian masa kini.

3. Tepat waktu

Informasi disajikan tepat waktu sehingga dapat berpengaruh dan berguna dalam pengambilan keputusan.

4. Lengkap

Informasi akuntansi keuangan pemerintah disajikan selengkap mungkin, yaitu mencakup semua informasi akuntansi yang dapat mempengaruhi pengambilan keputusan. Informasi yang melatarbelakangi setiap butir informasi utama yang termuat dalam laporan keuangan diungkapkan dengan jelas agar kekeliruan dalam penggunaan informasi

b. Andal tersebut dapat dicegah.

Informasi dalam laporan keuangan bebas dari pengertian yang menyesatkan dan kesalahan material, menyajikan setiap fakta secara jujur, serta dapat diverivikasi. Informasi mungkin relevan, tetapi jika hakikat atau penyajiannya tidak dapat diandalkan maka penggunaan informasi tersebut secara potensial dapat menyesatkan. Informasi yang andal memenuhi karakteristik:

1. Penyajian Jujur Informasi menggambarkan dengan jujur transaksi serta peristiwa lainnya yang seharusnya disajikan atau yang secara wajar dapat diharapkan untuk disajikan.

2. Dapat Diverifikasi (verifiability) 
Informasi yang disajikan dalam laporan keuangan dapat diuji, dan apabila pengujian dilakukan lebih dari sekali oleh pihak yang berbeda, hasilnya tetap menunjukkan simpulan yang tidak berbeda jauh.

3. Netralitas

Informasi diarahkan pada kebutuhan umum dan tidak berpihak pada kebutuhan pihak tertentu.

c. Dapat Dibandingkan

Informasi yang termuat dalam laporan keuangan akan lebih berguna jika dapat dibandingkan dengan laporan keuangan periode sebelumnya atau laporan keuangan entitas pelaporan lain pada umumnya. Perbandingan dapat dilakukan secara internal dan eksternal. Perbandingan secara internal dapat dilakukan bila suatu entitas menerapkan kebijakan akuntansi yang sama dari tahun ke tahun. Perbandingan secara eksternal dapat dilakukan bila entitas yang diperbandingkan menerapkan kebijakan akuntansi yang sama. Apabila entitas pemerintah akan menerapkan kebijakan akuntansi yang lebih baik daripada kebijakan akuntansi yang sekarang diterapkan, perubahan tersebut diungkapkan pada periode terjadinya perubahan.

d. Dapat Dipahami

Informasi yang disajikan dalam laporan keuangan dapat dipahami oleh pengguna dan dinyatakan dalam bentuk serta istilah yang disesuaikan dengan batas pemahaman para pengguna. Untuk itu, pengguna diasumsikan memiliki pengetahuan yang memadai atas kegiatan dan lingkungan operasi entitas pelaporan, serta adanya kemauan pengguna untuk mempelajari informasi yang dimaksud.

\section{Peraturan Pemerintah Nomor 71 tahun 2010}

Dalam mewujudkan tata kelola yang baik (good governance), pemerintah terus melakukan usaha-usaha meningkatkan transparansi dan akuntabilitas pengelolaan keungan negara. Usaha reformasi keungan negara mencakup bidang peraturan perundang-undangan, kelembagaan, sistem, dan peningkatan kualitas sumber daya manusia. Untuk dapat mencapai good governance diharapkan penyusunan dan penyajian laporan keungan dapat berpedoman pada sebuah standar akuntansi dalam rangka peningkatan kualitas laporan keuangan.

Prosedur pencatatan Menurut PP Nomor 71 tahun 2010 tentang Standar Akuntansi Pemeintah meliputi:

a. Pencatatan

Menurut Halim (2004:34) ada beberapa macam sistem pencatatan yang digunakan, yaitu

1. Sistem pencatatan single entry sering disebut juga dengan sistem tata buku tunggal atau tata buku saja. Dalam sistem ini, pencatatan transaksi ekonomi dilakukan dengan mencatatnya satu kali. Transaksi yang berakibat bertambahnya kas akan dicatat pada sisi Penerimaan dan transaksi yang berakibat berkurangnya kas akan dicatat pada sisi Pengeluaran.

2. Sistem pencatatan double entry sering disebut juga dengan sistem tata buku berpasangan. Menurut sistem ini, pada dasarnya suatu transaksi ekonomi akan dicatat dua kali (double = berpasangan/ganda, entry = pencatatan). Pencatatan dengan sistem ini disebut dengan istilah menjurnal. Dalam pencatatan tersebut ada sisi Debit dan Kredit. Sisi Debit ada disebelah Kiri sedangkan sisi Kredit ada di sebelah Kanan. Dalam melakukan pencatatan tersebut, setiap pencatatan harus menjaga keseimbangan persamaan dasar akuntansi.

3. Sistem pencatatan triple entry adalah pelaksanaan pencatatan dengan menggunakan sistem pencatatan double entry, ditambah dengan pencatatan pada buku anggaran. Jadi, sementara sistem pencatatan double entry dijalankan, satuan pemegang kas pada satuan kerja maupun pada bagian keuangan atau badan/biro pengelola kekayaan daerah juga mencatat transaksi tersebut pada buku anggaran, sehingga pencatatan tersebut akan berefek pada sisa anggaran.

b. Penggolongan dan Pengikhtisaran

Adanya penjurnalan dan melakukan posting ke buku besar sesuai dengan nomor perkiraan. 
c. Pelaporan

Setelah semua proses diatas selesai maka akan didapat laporan keuangan. Laporan keuangan tersebut berupa laporan realisasi anggaran, necara, laporan arus kas dan catatan atas laporan keuangan. Laporan keuangan disusun untuk menyediakan informasi yang relevan mengenai posisi keuangan dan seluruh transaksi yang dilakukan oleh suatu entitas selama satu periode pelaporan. Laporan keuangan tersebut oleh bagian keuangan akan dilaporkan kepada pihak-pihak yang memerlukannnya. Pihak-pihak yang memerlukannnya antara lain: Dewan Perwakilan Rakyat Daerah (DPRD); Badan Pengawasan Keuangan; Investor; Kreditor; dan donatur; Analisis Ekonomi dan Pemerhati Pemerintah Daerah; Rakyat; Pemerintah Daerah lain; dan Pemerintah Pusat yang semuanya ada dalam lingkungan akuntansi keuangan daerah.

Peranan laporan keuangan pemerintah menurut Peraturan Pemerintah No. 71 Tahun 2010 tentang Standar Akuntansi Pemerintah meliputi:

1. Akuntabilitas yaitu mempertanggungjawabkan pengelolaan sumber daya serta pelaksanaan kebijakan yang dipercayakan kepada entitas pelaporan dalam mencapai tujuan yang telah ditetapkan secara periodik.

2. Manajemen; Membantu para pengguna untuk mengevaluasi pelaksanaan kegiatan entitas pelaporan dalam periode pelaporan sehinggah memudahkan fungsi perencanaan, pengelolaan, dan pengendalian atas seluruh aset, kewajiban, dan ekuitas dana pemerintah untuk kepentingan masyarakat.

3. Transparansi: Memberikan informasi keuangan yang terbuka dan jujur kepada masyarakat berdasarkan pertimbangan bahwa masyarakat memiliki hak untuk mengetahui secara terbuka dan menyeluruh atas pertanggungjawaban pemerintah dalam pengelolaan sumber daya yang dipercayakan kepadanya dan ketaatanya pada peraturan perundang-undangan.

4. Keseimbangan Antargenerasi (intergenerational equity): Membantu para pengguna dalam mengetahui kecukupan penerimaan pemerintah pada periode pelaporan untuk membiayai seluruh pengeluaran yang dialokasikan dan apakah generasi yang akan datang diasumsikan akan ikut menanggung beban pengeluaran tersebut.

\section{Akuntabilitas Kinerja Keuangan}

Fenomena yang terjadi dalam perkembangan sektor publik di Indonesia dewasa ini adalah menguatnya tuntutan akuntabilitas atas lembaga-lembaga publik, baik di pusat maupun daerah. Akuntabilitas dapat diartikan sebagai bentuk kewajiban mempertanggungjawabkan keberhasilan atau kegagalan pelaksanaan misi organisasi dalam mencapai tujuan dan sasaran yang telah ditetapkan sebelumnya, melalui suatu media pertanggungjawaban yang dilaksanakan secara periodik.

Pada dasarnya, akuntabilitas adalah pemberian informasi dan pengungkapan (disclosure) atas aktivitas dan kinerja finansial kepada pihak-pihak yang berkepentingan. Pemerintah, baik pusat maupun daerah, harus dapat menjadi subyek pemberi informasi dalam rangka pemenuhan hak-hak publik yaitu hak untuk tahu, hak untuk diberi informasi, dan hak untuk didengar aspirasinya.

Akuntabilitas publik merupakan suatu bentuk pertanggungjawaban atas segala bentuk aktivitas yang dilakukan oleh seseorang pemegang amanah terhadap orang atau badan yang meminta pertanggungjawaban tersebut. Akuntabilitas ini dilakukan sebagai bentuk transparansi daripada kegiatan operasional suatu perusahaan.

Menurur Ulum (2004:40) Akuntabilitas adalah perwujudan kewajiban untuk mempertanggungjawabkan keberhasilan atau kegagalan atas pelaksanaan misi organisasi dalam mencapai tujuan-tujuan dan sasaran-sasaran yang telah ditetapkan melalui suatu media pertanggungjawaban secara periodik.

Menurut Ulum (2004:41) Akuntabilitas keuangan merupakan pertanggungjawaban mengenai:

a. Integritas Keuangan 
Menurut kamus Bahasa Indonesia, integritas adalah kejujuran, keterpaduan, kebulatan, keutuhan. Dengan kata lain integritas keuangan mencerminkan kejujuran penyajian. Kejujuran penyajian adalah bahwa harus ada hubungan atau kecocokan antara angka dan deskripsi akuntansi dan sumber-sumbernya. Integritas keuangan pun harus dapat menyajikan informasi secara terbuka mengenai laporan keuangan daerah.

Agar laporan keuangan dapat diandalkan informasi yang terkandung didalamnya harus menggambarkan dengan jujur transaksi serta peristiwa lainnya yang seharusnya disajikan atau yang secara wajar dapat diharapkan untuk disajikan.

Penyajian secara wajar yang dimaksud diatas terdapat didalam Peraturan Pemerintah No. 71 Tahun 2010, menyatakan Laporan keuangan menyajikan dengan wajar laporan realisasi anggaran, neraca dan laporan arus kas.

Faktor pertimbangan sehat bagi penyusunan laporan keuangan diperlukan ketika menghadapi ketidakpastian peristiwa dan keadaan tertentu. Ketidakpastian seperti itu diakui dengan pengungkapan hakikat serta tingkatnya dengan menggunakan pertimbangan sehat dalam penyusunan laporan keuangan. Pertimbangan sehat mengandung unsur kehatihatian pada saat melakukan prakiraan dalam kondisi ketidakpastian sehingga aset atau pendapatan tidak dinyatakan terlalu tinggi dan kewajiban tidak dinyatakan terlalu rendah.

Namun demikian, penggunaan pertimbangan sehat tidak memperkenankan, misalnya, pembentukan cadangan tersembunyi, sengaja menetapkan aset atau pendapatan yang terlampau rendah, atau sengaja mencatat kewajiban atau belanja yang terlampau tinggi, sehingga laporan keuangan menjadi tidak netral dan tidak andal.

b. Pengungkapan

Konsep full disclosure (pengungkapan lengkap) mewajibkan agar laporan keuangan didesain dan disajikan sebagai kumpulan potret dari kejadian ekonomi yang mempengaruhi instansi pemerintah untuk suatu periode dan berisi cukup informasi. Yang menyajikan secara lengkap informasi yang dibutuhkan oleh pengguna laporan keuangan sehingga membuat pemakai laporan keuangan paham dan tidak salah tafsir terhadap laporan keuangan tersebut.

Pengungkapan lengkap merupakan bagian dari prinsip akuntansi dan pelaporan keuangan, sehingga terdapat di dalam Peraturan Pemerintah No. 71 Tahun 2010 pada lampiran II paragraf 50, mengatakan Laporan keuangan menyajikan secara lengkap informasi yang dibutuhkan oleh pengguna. Informasi yang dibutuhkan oleh pengguna laporan keuangan dapat ditempatkan pada lembar muka laporan keuangan atau catatan atas laporan keuangan".

c. Ketaatan terhadap peraturan perundang-undangan

Akuntansi dan pelaporan keuangan pemerintah harus menunjukkan ketaatan terhadap peraturan perundang-undangan, antara lain:

1. Undang-undang Dasar Republik Indonesia khususnya yang mengatur mengenai keuangan Negara,

2. Undang-undang Perbendaharaan Indonesia,

3. Undang-undang APBN,

4. Peraturan perundang-undangan yang mengatur tentang pemerintah daerah,

5. Peraturan perundang-undangan yang mengatur tentang perimbangan keuangan pusat dan daerah,

6. Ketentuan perundang-undangan yang mengatur tentang pelaksanaan APBN/APBD,

7. Peraturan perundang-undangan lainnya yang mengatur tentang keuangan pusat dan daerah.

Menurut Mahmudi (2005:10) Akuntabilitas publik yang harus dilakukan oleh organisasi sektor publik terdiri atas beberapa dimensi:

a. Akuntabilitas Kejujuran dan Hukum

Akuntabilitas kejujuran terkait dengan penghindaran penyalahgunaan jabatan, sedangkan akuntabilitas hukum terkait dengan jaminan adanya kepatuhan terhadap hukum dan peraturan lain yang disyaratkan dalam penggunaan sumber dana publik.

b. Akuntabilitas Manajerial 
Akuntabilitas manajerial terkait apakah prosedur yang digunakan dalam melaksanakan tugas sudah cukup baik dalam hal kecukupan sistem informasi akuntansi, sistem informasi manajemen, dan prosedur administrasi.

c. Akuntabilitas Program

Akuntabilitas program terkait dengan pertimbangan apakah tujuan yang ditetapkan dapat dicapai atau tidak, dan apakah telah mempertimbangkan alternatif program yang memberikan hasil yang optimal dengan biaya yang minimal.

d. Akuntabilitas Kebijakan

Akuntabilitas kebijakan terkait dengan pertanggungjawaban pemerintah, baik pusat maupun daerah, atas kebijakan-kebijakan yang diambil pemerintah terhadap DPR/DPRD dan masyarakat luas.

e. Akuntabilitas Finansial

Akuntabilitas finansial adalah pertanggungjawaban lembaga-lembaga publik, untuk menggunakan uang publik (publik money) secara ekonomi, efisien, dan efektif, tidak ada pemborosan dan kebocoran dana serta korupsi. Akuntabilitas finansial sangat penting karena pengelolaan keuangan publik akan menjadi perhatian utama masyarakat. Akuntabilitas finansial mengharuskan lembaga-lembaga publik untuk membuat laporan keuangan untuk menggambarkan kinerja finansial organisasi kepada pihak luar. Akuntansi sektor publik memiliki peran yang sangat penting dalam mendorong terciptanya akuntabilitas finansial. Kekuatan utama akuntansi adalah pada pemberian informasi. Informasi merupakan bahan dasar untuk proses pengambilan keputusan untuk menghasilkan produk berupa keputusan. Dalam konteks organisasi sektor publik, keputusan yang diambil harus memenuhi prinsip akuntabilitas publik terutama terkait dengan akuntabilitas kebijakan.oleh karena itu, kualitas informasi berupa keakuratan, transparansi, ketepatan waktu, validitas, relevansi dan keandalan informasi akan sangat mempengaruhi kualitas keputusan dan akuntabilitas publik.

\section{Pengukuran Kinerja}

Menurut Mahsun, Sulistyowati dan Purwanu (2007:157) Kinerja (performance) adalah gambaran mengenai tingkat pencapaian pelaksanaan suatu kegiatan/program/kebijakan dalam mewujudkan sasaran, tujuan, misi dan visi organisasi yang tertuang dalam strategic planning suatu organisasi.

Menurut Robertson (dalam Mahsun, Sulistyowati dan Purwanu 2007:157), pengukuran kinerja (performance measurement) adalah suatu proses penilaian kemajuan pekerjaan terhadap tujuan dan sasaran yang telah ditentukan sebelumnya, termaksud informasi atas: efisiensi, penggunaan sumber daya dalam menghasilkan barang dan jasa, kualitas barang dan jasa (seberapa baik barang dan jasa diserahkan kepada pelanggan dan sampai seberapa jauh pelanggan terpuaskan), hasil kegiatan dibandingkan dengan maksud yang diinginkan, dan efektivitas tindakan dalam mencapai tujuan.

Prestasi pelaksanaan program dapat diukur untuk mendorong pencapaian prestasi tersebut. Pengukuran prestasi yang dilakukan secara berkelanjutan memberikan umpan balik untuk upaya perbaikan secara terus menerus dan pencapaian tujuan dimasa mendatang.

Peranan pengukuran prestasi sebagai alat manajemen untuk (Bastian 2006:330):

a. Memastikan pemahaman para pelaksana dan ukuran yang digunakan untuk pencapaian prestasi.

b. Memastikan tercapainya skema prestasi yang disepakati.

c. Memonitor dan mengevaluasi kinerja dengan pembanding skema kerja dan pelaksanaan.

d. Memberikan penghargaan dan hukuman yang objektif atas prestasi pelaksanaanyang telah diukur sesuai dengan sistem pengukuran prestasi yang telah disepakati.

e. Menjadikan alat komunikasi antar bawahan dan pimpinan dalam upaya memperbaiki prestasi organisasi.

f. Mengidentifikasi apakah kepuasan pelanggan sudah terpenuhi.

g. Membantu memahami proses kegiatan instansi pemerintahan. 
h. Memastikan bahwa pengambilan keputusan dilakukan secara objektif.

i. Menunjukkan peningkatan yang perlu dilakukan.

j. Mengungkapkan permasalahan yang terjadi.

Pengukuran kinerja biasanya dilakukan untuk aspek-aspek berikut ini (Bastian 2006:331):

a. Aspek Finansial.

Aspek finansial meliputi anggaran atau cash flow. Aspek finansial ini sangat penting diperhatikan dalam pengukuran kinerja sehingga Dianalogikan sebagai aliran darah dalam tubuh manusia.

b. Kepuasan Pelanggan.

Dalam globalisasi perdagangan,peran dan posisi pelanggan sangat krusial dalam penentuan strategi perusahaan. Untuk itu, manajemen perlu memperoleh informasi yang relevan tentang tingkat kepuasan pelanggan.

c. Operasi dan Pasar Internal.

Informasi operasi dan mekanisme pasar internal diperlukan untuk memastikan bahwa seluruh kegiatan organisasi dirancang untuk pencapaian tujuan dan sasaran organisasi. Disamping itu, informasi operasi dan pasar internal menentukan tingkat efisiensi dan efektivitas operasi organisasi.

d. Kepuasan Pegawai.

Dalam organisasi yang banyak melakukan inovasi, peran strategis pegawai amat menentukan kelangsungan organisasi.

e. Kepuasan Komunitas dan Stakholders.

Pengukuran kinerja perlu dirancang untuk mengakomodasi kepuasan para stakeholders.

f. Waktu

Informasi untuk pengukuran harus informasi terbaru, sehingga manfaat hasil pengukuran kinerja dapat dimaksimalkan.

Mekanisme pengukuran kinerja dapat dilaksanakan dengan memperhatikan hal-hal sebagai berikut:

a. Membuat komitmen dan menjalankan pengukuran kinerja.

Hal yang perlu dilakukan oleh instansi adalah sesegera mungkin membuat komitmen pengukuran kinerja, dan menjalankannya dengan tidak mengharapkan pengukuran kinerja akan langsung sempurna, untuk itu perlu dilakukan evaluasi terhadap pengukuran kinerja tersebut.

b. Perlakuan pengukuran kinerja sebagai suatu proses yang berkelanjutan.

Pengukuran kinerja merupakan suatu proses yang bersifat interaktif. Proses ini merupakan suatu cerminan upaya organisasi untuk memperbaiki kinerja.

c. Menyesuaikan proses pengukuran kinerja dengan organisasi

Organisasi harus menetapkan ukuran kinerja yang sesuai dengan bentuk dan besarnya organisasi, budaya, visi, tujuan, sasaran, dan struktur organisasi.

\section{Kerangka Analisis}

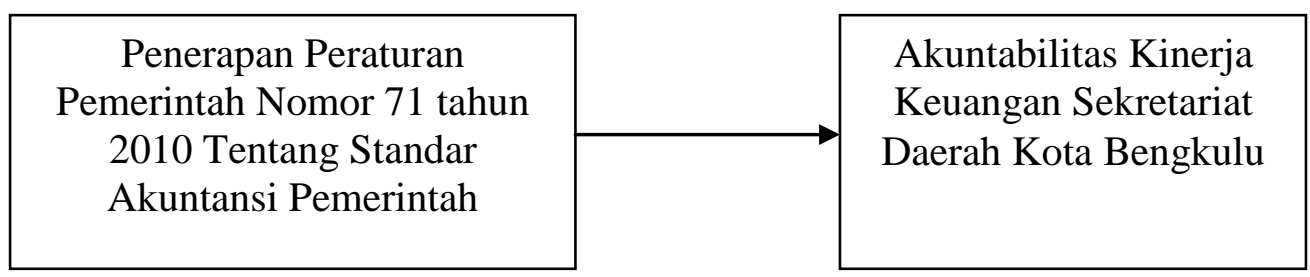

Variabel X

Variabel Y

Gambar 1. Kerangka Analisis 


\section{HASIL PENELITIAN DAN PEMBAHASAN Karakteristik Responden}

Berdasarkan penyebaran kuesioner kepada responden penelitian sebanyak 15 orang pegawai bagian keuangan pada Sekretariat Daerah Kota Bengkulu, maka didapatkan data karaktersitik dari responden tersebut berdasarkan umur, jenis kelamin pendidikan terakhir dan lama bekerja sebagai berikut:

Tabel 5. Rekapitulasi Karakteristik Responden

\begin{tabular}{|l|c|c|}
\hline \multicolumn{1}{|c|}{ Karakteristik Responden } & Jumlah Responden & Persentase \\
\hline Jenis Kelamin: & 9 & $60 \%$ \\
Pria & 6 & $40 \%$ \\
Wanita & 2 & $13,3 \%$ \\
\hline Usia & 6 & $40 \%$ \\
21-30 tahun & 3 & $20 \%$ \\
31-40 tahun & 4 & $26,7 \%$ \\
41-50 tahun & & \\
$>50$ tahun & 3 & $20 \%$ \\
\hline Pendidikan Terakhir: & 2 & $13,3 \%$ \\
SLTA-DI & 10 & $66,7 \%$ \\
DII-DIII & - & - \\
SI-SII & & \\
Lainnya & 10 & $66,7 \%$ \\
\hline Jabatan: & 5 & $33,3 \%$ \\
Pelaksana & & \\
Staf Keuangan & 6 & $40 \%$ \\
\hline Lama Bekerja: & 4 & $26,7 \%$ \\
1-10 tahun & 3 & $20 \%$ \\
11-20 tahun & 2 & $13,3 \%$ \\
21-30 tahun & & \\
\hline 30 tahun & & \\
\hline
\end{tabular}

Sumber: Data diolah, 2013

Berdasarkan tabel 4 di atas dapat diketahui bahwa dari 15 responden berdasarkan jenis kelamin meliputi pria sebanyak $9(60 \%)$ rseponden dan wanita sebanyak $6(40 \%)$ responden. Sedangkan, untuk usia responden 21-30 tahun sebanyak 2 (13,3\%) responden, 31-40 tahun sebanyak $6(40 \%)$ responden, 41-50 tahun sebanyak 3 (20\%) responden dan usia >50 tahun sebanyak $4(26,7 \%)$ responden.

Selain itu, dari tabel 4 di atas dapat diketahui latar belakang pendidikan responden yang paling banyak adalah tingkat Strata 1 (S1) sampai dengan Strata 2 (S2) yaitu sebanyak 10 $(66,7 \%)$ responden. Sedangkan berdasarkan jabatan responden paling banyak adalah jabatan pelaksana yaitu sebanyak $10(66,7 \%)$ responden. Lama bekerja responden paling banyak adalah 1-10 tahun yaitu sebanyak $6(40 \%)$ responden.

\section{Distribusi Rata Rata Tanggapan Responden}

Analisis distribusi rata-rata digunakan untuk menguji sejauh mana tanggapan responden terhadap penerapan PP Nomor 71 tahun 2010 dengan akuntabilitas kinerja laporan keuangan daerah. Adapun hasil dari distribusi rata-rata tanggapan responden di Bagian Keuangan Sekretariat Daerah Kota Bengkulu adalah sebagai berikut:

1. Distribusi rata-rata untuk penerapan PP Nomor 71 tahun 2010

Penerapan Standar Akuntansi Pemerintah (SAP) merupakan keharusan bagi pemerintah daerah, apalagi setelah pemerintah pusat sudah mengeluarkan Peraturan Pemerintah Nomor 71 tahun 2010, tentang Standar Akuntansi Pemerintah. Pemerintah mengharapkan dengan 
diterapkannya standar tersebut dapat mewujudkan akuntabilitas laporan keuangan daerah. Berdasarkan penyebaran kuesioner kepada 15 orang di Bagian Keuangan Sekretariat Daerah Kota Bengkulu. Jawaban responden mengenai Penerapan PP Nomor 71 tahun 2010 pada Sekretariat Daerah Kota Bengkulu adalah sebagai berikut:

Tabel 6. Distribusi Rata Rata Penerapan PP Nomor 71 tahun 2010 (X)

\begin{tabular}{|c|c|c|c|c|c|c|c|c|}
\hline \multirow[t]{2}{*}{ No Pertanyaan } & \multicolumn{5}{|c|}{ Skor } & \multirow[t]{2}{*}{ Total Res } & \multirow[t]{2}{*}{ Total } & \multirow[t]{2}{*}{ Rata rata } \\
\hline & SS & $\mathbf{S}$ & $\mathbf{R R}$ & TS & STS & & & \\
\hline 1 & 14 & 1 & - & - & - & 15 & 74 & 4,93 \\
\hline 2 & 9 & 6 & - & - & - & 15 & 69 & 4,60 \\
\hline 3 & - & - & - & 4 & 11 & 15 & 19 & 1,25 \\
\hline 4 & 12 & 3 & & & & 15 & 72 & 4,80 \\
\hline 5 & - & - & - & 3 & 12 & 15 & 18 & 1,20 \\
\hline 6 & 7 & 8 & - & - & - & 15 & 67 & 4,45 \\
\hline 7 & - & - & - & 5 & 10 & 15 & 20 & 1,33 \\
\hline 8 & 11 & 4 & & & & 15 & 71 & 4,73 \\
\hline 9 & - & - & - & 3 & 12 & 15 & 18 & 1,20 \\
\hline 10 & 11 & 4 & - & - & - & 15 & 71 & 4,73 \\
\hline 11 & - & - & - & 4 & 11 & 15 & 19 & 1,25 \\
\hline 12 & 12 & 3 & - & - & - & 15 & 72 & 4,80 \\
\hline 13 & - & - & - & 3 & 12 & 15 & 18 & 1,20 \\
\hline 14 & 7 & 8 & - & - & - & 15 & 67 & 4,45 \\
\hline 15 & 9 & 6 & - & - & - & 15 & 69 & 4,60 \\
\hline \multicolumn{6}{|c|}{ Jumlah } & 15 & 744 & 49,52 \\
\hline \multicolumn{6}{|c|}{ Distribusi Rata Rata } & 15 & 49,6 & 3,30 \\
\hline
\end{tabular}

Sumber : Data diolah, 2013

Dari tabel 6 di atas menunjukan bahwa distribusi rata-rata dari tanggapan responden terhadap Penerapan Peraturan Pemerintah Nomor 71 tahun 2010 tentang Standar Akuntansi Pemerintah adalah cukup baik, yaitu dengan jumlah rata-rata 3,30 dikatakan cukup baik karena jumlah nilai rata-rata variable komponen penerapan PP Nomor 71 tahun 2010 berada pada interval 2,61 - 3,40 (Cukup Baik).

Berdasarkan hasil analisis distribusi rata-rata pertanyaan nomor 1 yang menujukan angka tertinggi yaitu 4,93. Dimana pencatatan yang dilakukan oleh Sekretariat Daerah Kota Bengkulu khususnya bagian keuangan, melakukan pencatatannya dengan menggunakan sistem pencatatan double entry dan menggunakan cash basis selama tahun anggaran dan melakukan penyesuaian pada akhir tahun anggaran berdasarkan accrual basis untuk pengakuan asset, kewajiban dan ekuitas pemerintah.

Sehingga dapat disimpulkan Penerapan PP Nomor 71 tahun 2010 tentang Standar Akuntansi Pemerintah (SAP) pada Sekretariat Daerah Kota Bengkulu dikatakan cukup baik, karena standar akuntansi pemerintah Sekretariat Daerah Kota Bengkulu sudah memenuhi kriteria yang terdiri dari pencatatan, penggolongan dan pengikhtisaran, serta pelaporan hal tersebut telah sesuai dengan teori yang dikemukakan dalam Peraturan Pemerintah Nomor 71 tahun 2010 tentang standar akuntansi pemerintah.

2. Distribusi rata rata pelaksanaan akuntabilitas kinerja laporan keuangan daerah.

Akuntabilitas dapat diartikan sebagai bentuk kewajiban mempertanggungjawabkan keberhasilan atau kegagalan pelaksanaan misi organisasi dalam mencapai tujuan dan sasaran yang telah ditetapkan sebelumnya, melalui suatu media pertanggungjawaban yang dilaksanakan secara periodik. Berdasarkan penyebaran kuesioner kepada 15 orang di Bagian Keuangan Sekretariat Daerah Kota Bengkulu. Jawaban responden mengenai akuntabilitas kinerja laporan keuangan pada Sekretariat Daerah Kota Bengkulu adalah sebagai berikut: 
Tabel 7. Distribusi Rata Rata Variabel Akuntabilitas Kinerja Laporan Keuangan

\begin{tabular}{|c|c|c|c|c|c|c|c|c|}
\hline \multirow{2}{*}{$\begin{array}{c}\text { No } \\
\text { Pertanyaan }\end{array}$} & \multicolumn{5}{|c|}{ Skor } & \multirow[t]{2}{*}{ Jumlah Res } & \multirow[t]{2}{*}{ Skor } & \multirow{2}{*}{$\begin{array}{l}\text { Rata } \\
\text { Rata }\end{array}$} \\
\hline & SS & $S$ & $\mathbf{R R}$ & TS & STS & & & \\
\hline 1 & 13 & 2 & - & - & - & 15 & 73 & 4,85 \\
\hline 2 & - & - & - & 4 & 11 & 15 & 19 & 1,25 \\
\hline 3 & 13 & 2 & - & - & - & 15 & 73 & 4,83 \\
\hline 4 & - & - & - & 2 & 13 & 15 & 17 & 1,13 \\
\hline 5 & 13 & 2 & - & - & - & 15 & 73 & 4,85 \\
\hline 6 & - & - & - & 7 & 8 & 15 & 22 & 1,45 \\
\hline 7 & 11 & 4 & - & - & - & 15 & 71 & 4,73 \\
\hline 8 & - & - & - & 3 & 12 & 15 & 18 & 1,20 \\
\hline 9 & 6 & 9 & - & - & - & 15 & 66 & 4,40 \\
\hline 10 & 13 & 2 & - & - & - & 15 & 73 & 4,83 \\
\hline 11 & - & - & - & 1 & 14 & 15 & 16 & 1,05 \\
\hline 12 & 13 & 2 & . & & & 15 & 73 & 4,83 \\
\hline 13 & - & - & - & 3 & 12 & 15 & 18 & 1,20 \\
\hline 14 & 8 & 7 & - & - & - & 15 & 68 & 4,53 \\
\hline 15 & - & - & - & 4 & 11 & 15 & 19 & 1,25 \\
\hline & & Ilal & & & & 15 & 699 & 46,38 \\
\hline & Dist & $\mathbf{R a}$ & Rata & & & 15 & 46,6 & 3,09 \\
\hline
\end{tabular}

Sumber : Data diolah, 2013

Dari tabel 7 di atas menunjukan bahwa distribusi rata-rata dari tanggapan responden terhadap Akuntabilitas Kinerja Laporan Keuangan adalah cukup baik, yaitu dengan jumlah ratarata 3,09 dikatakan cukup baik karena jumlah nilai rata-rata variable komponen akuntabilitas kinerja laporan keuangan berada pada interval 2,61- 3,40 (Cukup Baik).

Berdasarkan hasil analisis distribusi rata-rata pertanyaan nomor 1, 3 dan 10 yang menujukan angka tertinggi yaitu 4,83. Dimana Integritas dapat diartikan sebagai kejujuran, keterpaduan, kebulatan dan keutuhan. Informasi yang diberikan Sekretariat Daerah Kota Bengkulu mengenai laporan keuangannya sudah terbuka dan telah mentaati peraturan perundang-undangan yang berlaku. Hal ini terlihat dari laporan keuangan yang berpedoman pada Peraturan Menteri Dalam Negeri No. 13 Tahun 2011.

Sehingga dapat disimpulkan bahwa akuntabilitas kinerja laporan keuangan pada Sekretariat Daerah Kota Bengkulu dikatakan cukup baik, karena dalam mewujudkan integritas keuangan, pengungkapan laporan keuangan dan ketaatan terhadap peraturan perundangundangan telah sesuai dengan ketentuan dan kebijakan yang berlaku.

\section{Korelasi Spearman Rank}

Tujuan pengujian korelasi spearman rank adalah untuk menentukan apakah jawaban teoritis yang terkandung dalam pernyataan hipotesis didukung oleh fakta yang dikumpulkan dan dianalisis dalam pengujian data. Metode pengujian ini dilakukan untuk menguji kebenaran antara variabel serta sesuai untuk sampel yang kecil.

Sebelum untuk mencari korelasi spearman rank terlebih dahulu butir-butir instrumen dibelah menjadi dua kelompok yaitu kelompok instrumen ganjil dan kelompok instrumen genap selanjutnya skor total dari dua kelompok tersebut sebagai dasar untuk mencari korelasi spearman rank nantinya metode tersebut adalah dalam Split Half Methode. Adapun hasil dari teknik belah dua tersebut adalah sebai berikut: 
Tabel 8. Skor Kelompok Ganjil dan Kelompok Genap

\begin{tabular}{|c|c|c|}
\hline Responden & Skor Kelompok Ganjil & Skor Kelompok Genap \\
\hline 1 & 74 & 73 \\
\hline 2 & 46 & 42 \\
\hline 3 & 44 & 48 \\
\hline 4 & 48 & 41 \\
\hline 5 & 43 & 48 \\
\hline 6 & 46 & 43 \\
\hline 7 & 43 & 48 \\
\hline 8 & 45 & 44 \\
\hline 9 & 39 & 45 \\
\hline 10 & 71 & 73 \\
\hline 11 & 18 & 17 \\
\hline 12 & 72 & 73 \\
\hline 13 & 18 & 19 \\
\hline 14 & 65 & 70 \\
\hline 15 & 45 & 43 \\
\hline Jumlah & 717 & 727 \\
\hline
\end{tabular}

Sumber: Data diolah, 2013

Berdasarkan tabel 8 di atas maka dapat dihitung korelasinya antara Penerapan PP nomor 71 tahun 2010 terhadap akuntabilitas kinerja laporan keuangan daerah dengan menggunakan tabel penolong perhitungan korelasi spearman rank sebagai berikut:

Tabel 9. Tabel Penolong Perhitungan Korelasi Speraman Rank

\begin{tabular}{|c|c|c|c|c|c|c|}
\hline No Responden & $\mathbf{X}$ & $\mathbf{Y}$ & $\mathbf{X i}$ & $\mathbf{Y i}$ & $\mathbf{b i}$ & $\mathbf{b i}^{\mathbf{2}}$ \\
\hline 1 & 74 & 73 & 1 & 2 & -1 & 1 \\
\hline 2 & 46 & 42 & 6,5 & 12 & $-5,5$ & 30.25 \\
\hline 3 & 44 & 48 & 10 & 6 & 4 & 16 \\
\hline 4 & 48 & 41 & 5 & 13 & -8 & 64 \\
\hline 5 & 43 & 48 & 11,5 & 6 & 5,5 & 30,25 \\
\hline 6 & 46 & 43 & 6,5 & 10,5 & -4 & 16 \\
\hline 7 & 43 & 48 & 11,5 & 6 & 5,5 & 30,25 \\
\hline 8 & 45 & 44 & 8,5 & 9 & 0,5 & 0,25 \\
\hline 9 & 39 & 45 & 13 & 8 & 5 & 25 \\
\hline 10 & 71 & 73 & 3 & 2 & 1 & 1 \\
\hline 11 & 18 & 17 & 14,5 & 15 & $-0,5$ & 0,25 \\
\hline 12 & 72 & 73 & 2 & 2 & 0 & 0 \\
\hline 13 & 18 & 19 & 14,5 & 14 & 0,5 & 0,25 \\
\hline 14 & 65 & 70 & 4 & 4 & 0 & 0 \\
\hline 15 & 45 & 43 & 8,5 & 10,5 & -2 & 4 \\
\hline Jumlah & & & & & & 218.5 \\
\hline
\end{tabular}

Sumber: Data Diolah, 2013

Selanjutnya nilai $\mathrm{bi}^{2}$ yang diperoleh dari hitungan tabel 9 di atas dimasukan dalam rumus korelasi spearman rank sebagai berikut:

$$
\rho=1-\frac{6 \sum b i^{2}}{n\left(n^{2}-1\right)}
$$




$$
\begin{aligned}
& \rho=1-\frac{6 \cdot(218,5)}{15\left(15^{2}-1\right)}=1-0,39 \\
& \rho=0,61
\end{aligned}
$$

\section{Uji Hipotesis}

Pengujian hipotesis dihitung berdasarkan perhitungan korelasi rank spearman dimana jika Rhohitung $>$ dari Rhotabel , maka Ho ditolak, Ha diterima, jika Rho ${ }_{\text {hitung }}<$ dari Rhotabel , maka Ho diterima, Ha ditolak. Untuk mengetahui nilai $\mathrm{Rho}_{\text {tabel }} \mathrm{n}=15$ maka diperlukan dicari dengan interpolasi antara $n=14$ dengan nilai $R h o=0,544$ dan $n=16$ dengan nilai $R h o=0,506$ sehingga untuk mengetahui nilai Rho untuk $n=15$ adalah sebagai berikut:

Gambar 3. Interpolasi $n=15$

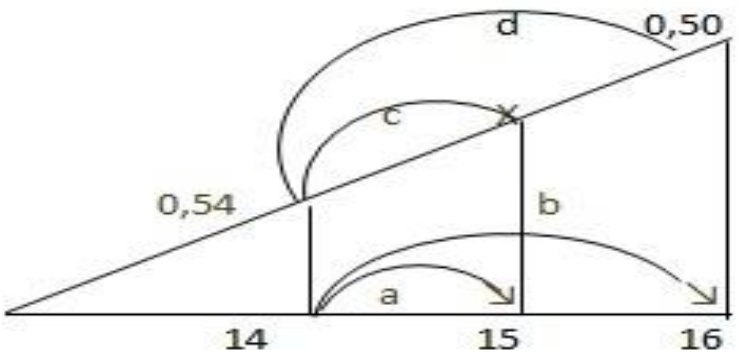

Sumber: Sugiyono, 2010:313

Dari gambar 3 di atas dapat dibuat persamaan untuk mencari nilai x yang merupakan nilai rho pada $\mathrm{n}=15$. Jadi persamaannya sebagai berikut:

$$
\begin{aligned}
\text { a }: \text { b } & =c \\
(15-14):(16-14) & =(X-0,544) \\
1 \quad: 2 & =(X-0,544): \\
2 X \quad: 2.0,544 & =1 .(-0,038) \\
2 X-1,088 & =-0,036 \\
2 X & =1,088-0,038=0,525
\end{aligned}
$$

Untuk menginterprestasikan angka tersebut maka perlu dibandingkan dengan nilai tabel rho. Dari tabel terlihat bahwa untuk $n=15$, pada taraf kesalahan 5\% diperoleh nilai 0,525. Hasil rho hitung ternyata lebih besar dari rho tabel untuk taraf kesalahan 5\% . Hal ini berarti Ha diterima dan Ho ditolak. Sehingga dapat disimpulkan hasil pengujian hipotesis bahwa Penerapan PP Nomor 71 tahun 2010 mempunyai pengaruh yang signifikan dan positif dalam menunjang akuntabilitas laporan keuangan daerah.

Untuk mengetahui tingkat hubungan koefisien korelasi penerapan Peraturan Pemerintah Nomor 71 tahun 2010 dengan akuntabilitas kinerja laporan keuangan di Sekretariat daerah Kota Bengkulu dapat diketahui sebagai berikut:

Tabel 10. Tingkat Hubungan Interprstasi Koefisien Korelasi

\begin{tabular}{|c|l|l|}
\hline 1. & $0,00-<0,20$ & Hubungan sangat lemah \\
\hline 2. & $\geq 0,20-<0,40$ & Hubungan rendah \\
\hline 3. & $\geq 0,40-<0,70$ & Hubungan sedang / cukup \\
\hline 4. & $\geq 0,70-<0,90$ & Hubungan kuat / tinggi \\
\hline 5. & $\geq 0,90-\leq 1,00$ & Hubungan sangat kuat / tinggi \\
\hline
\end{tabular}

Sumber: Sugiyono 2010:313

Nilai koefisien korelasi Peraturan Pemerintah Nomor 71 tahun 2010 tentang Standar Akuntansi Pemerintah berpengaruh terhadap akuntabilitas kinerja laporan keuangan daerah 
adalah 0,61 maka hubungan interprestasi koefisien korelasi termasuk dalam hubungan yang cukup kuat.

\section{Pembahasan}

Dari hasil pengolahan data baik pengujian hipotesis didapat koefisien korelasi rank spearman sebesar 0,61 maka hubungan koefisien korelasi termasuk kedalam hubungan yang cukup kuat karena pengaruh standar akuntansi pemerintah mempunyai pengaruh yang sangat kuat terhadap akuntabilitas kinerja laporan keuangan daerah atau adanya korelasi searah antara variabel-variabel yang diuji, setiap kenaikan nilai variabel $(\mathrm{X})$ yaitu standar akuntansi pemerintah diikuti dengan nilai variabel $(\mathrm{Y})$ yaitu akuntabilitas kinerja laporan keuangan daerah.

Peraturan Pemerintah Nomor 71 tahun 2010 tentang Standar Akuntansi Pemerintah (SAP) pada Sekretariat Daerah Kota Bengkulu yang sesuai dengan SAP mulai dilaksanakan sejak tahun 2006. Tahap awal dilakukan secara manual, kemudian seiring dengan perjalanan waktu, sejak tahun 2007 untuk membuat Laporan Realisasi Anggaran telah dibuat secara komputerisasi. Dengan begitu, kesalahan pencatatan dan kesalahan lain dapat terdeteksi dengan cepat, sehingga dapat meminimalkan pekerjaan berulang-ulang. Sistem Akuntansi Keuangan Daerah (SAKD) dilaksanakan berdasarkan pada Standar Akuntansi Pemerintahan (SAP) sesuai dengan PP Nomor 71 Tahun 2010.

Kebijakan daerah sangat perhatian terhadap peraturan-paraturan baru tentang pengelolaan keuangan, sehingga laporan keuangan yang dihasilkannya selalu sesuai dengan peraturan perundang-undangan yang terbaru. Manfaat dilakukannya penerapan Peraturan Pemerintah Nomor 71 tahun 2010 adalah agar dalam pelaksanaan pengelolaan keuangan dapat menerapkan prinsip akuntansi dan pelaporan keuangan yang sesuai dengan standar, standar dalam hal ini menggunakan standar akuntansi pemerintahan (SAP). Selain itu dalam menyusun laporan keungan pun dapat lebih mudah dan cepat dilakukan, penelusuran dan koreksi lebih mudah dideteksi, sehingga informasi yang diperlukan oleh pimpinan dapat terpenuhi.

Dari hasil penelitian diketahui bahwa pelaksanaan Sistem Akuntansi Keuangan Daerah (SAKD) telah sesuai dengan prinsip akuntansi dan pelaporan keuangan yang diatur berdasarkan Standar Akuntansi Pemerintahan (SAP). Berikut adalah informasi yang menunjukkan bahwa prinsip akuntansi dan pelaporan keuangan yang dilaksanakan Bagian Keuangan pada Sekretariat Daerah Kota Bengkulu telah disusun berdasarkan SAP:

a. Basis akuntansi yang digunakan adalah basis kas untuk pengakuan pendapatan, belanja dan pembiayaan. Basis kas adalah basis akuntansi yang mengakui pengaruh transaksi dan peristiwa lainnya pada saat kas diterima atau dibayar. Basis akrual digunakan untuk pengukuran aset, kewajiban, dan ekuitas dana. Basis akrual adalah basis akuntansi yang mengakui pengaruh transaksi atau peristiwa lainnya pada saat transaksi atau peristiwa itu terjadi tanpa memperhatikan saat kas atau setara kas diterima.

b. Pada prinsip nilai historis, aset dicatat sebasar pengeluaran kas dan setara kas yang dibayar atau sebesar nilai wajar dari imbalan untuk memperoleh asset tersebut pada saat perolehan. Kewajiban dicatat sejumlah kas dan setara kas yang diharapkan akan dibayarkan untuk memenuhi kewajiban dimasa yang akan datang untuk pelaksanaan kegiatan pemerintah.

c. Pada prinsip realisasi bagi Sekretariat Daerah Kota Bengkulu, pendapatan yang tersedia yang telah diotorisasikan melalui anggaran pemerintah selama suatu tahun fiskal akan digunakan untuk membayar hutang dan belanja dalam periode tersebut.

d. Pada prinsip substansi mengungguli bentuk formal, informasi disajikan dengan wajar atas transaksi atau peritiwa yang lain yang memang seharusnya disajikan sesuai dengan substansi dan realitas ekonomi, dan bukan berdasarkan aspek formalitasnya saja.

e. Pada prinsip periodisitas, kegiatan akuntansi dan pelaporan keuangan dilakukan dengan membagi-bagi menjadi beberapa periode, yang biasa dibuat adalah untuk periode satu tahunan dan triwulanan.

f. Pada prinsip konsistensi, Bagian Keuangan Sekretariat Daerah Kota Bengkulu selalu menggunakan metode akuntansi yang sama dari periode ke periode berikutnya. 
g. Pada prinsip pengungkapan lengkap, laporan keuangan selalu disajikan dengan lengkap sesuai dengan kebutuhan pengguna, dan informasi tersebut tersedia dalam Catatan Atas Laporan Keuangan.

h. Pada prinsip penyajian wajar, laporan keuangan disajikan secara wajar, apabila terjadi ketidakpastian peristiwa atau keadaan tertentu, aset atau pendapatan tidak dinyatakan terlalu tinggi dan kewajiban tidak dinyatakan terlalu rendah.

Berdasarkan informasi tersebut diatas, dapat dikatakan bahwa Peraturan Pemerintah Nomor 71 tahun 2010 tentang Standar Akuntansi Pemerintah (SAP) sangat bermanfaat bagi Sekretariat Daerah Kota Bengkulu dan telah dapat melaksanakan pencatatan, penggolongan, peringkasan dan pelaporan keuangan yang sangat sesuai dengan Standar Akuntansi Pemerintahan (SAP). Selain itu laporan keuangan Sekretariat Daerah Kota Bengkulu telah menggunakan sistem pencatatan double entry, SAP dilaksanakan oleh entitas pelaporan yaitu Satuan Kerja Perangkat Daerah (SKPD), dan kebijakan akuntansinya ditetapkan oleh Walikota sebagai Kepala Daerah.

Dalam upaya meningkatkan akuntabilitas kinerja laporan keuangan yang akuntabel Sekretariat Daerah Kota Bengkulu melakukan pengungkapan yang bersifat material, dimana pengungkapan yang bersifat material dilakukan secara transparan kepada masyarkat luas. Sekretariat Daerah Kota Bengkulu memberikan keleluasaan pada masyarakat umum, Dewan Perwakilan Rakyat Daerah (DPRD), Inspektorat Daerah Kota, donatur, investor, dan kreditor untuk memproleh informasi khususnya untuk mengetahui apa yang telah dicapai oleh Sekretariat Daerah Kota Bengkulu dalam mengelola keuangan daerah. Pelaksanaan akuntabilitas yang terdapat dalam ukuran variabel tersebut adalah:

a. Integritas Keuangan

Berdasarkan penelitian yang telah dilakukan, laporan keuangan Sekretariat Daerah Kota Bengkulu telah menunjukkan integitas yang tinggi. Hal tersebut terlihat dalam laporan keuangan yang telah menyajikan informasi keuangan secara lengkap mulai dari perolehan sumber dana, perolehan dana dan penyusunan pelaporan atas perolehan, pengelolaan dan penggunaan dana tersebut.

Melalui laporan keuangan tersebut dapat diketahui dari mana asal sumber dana Sekretariat Daerah Kota Bengkulu, serta bahwa dana tersebut telah digunakan sesuai dengan kebutuhan. Pengelolaan dana pemerintah juga telah dipercayakan kepada orang-orang yang memiliki kualitas keandalan dan kejujuran yang tinggi, serta dilaksanakan secara tertib dan taat hukum, sehingga tingkat pertanggungjawabannya dapat diandalkan.

Laporan keuangan Sekretariat Daerah Kota Bengkulu dapat diuji kebenarannya, hal tersebut didukung penuh dengan adanya pengawasan oleh Badan Pengelola Keuangan Pemerintah (BPKP), Inspektorat Daerah Kota dan Badan Pemeriksa Keuangan (BPK). Penyusunan laporan keuangan telah dilaksanakan dengan metode komputerisasi yang memuat jumlah pendapatan dan belanja yang dianggarakan dan direalisasikan, serta selisih atau perbedaan antara yang direncanakan dan yang direalisasikan secara lebih terjamin dan diharapkan akan mampu mengatasi berbagai permasalahan anggaran seperti kebocoran, pemborosan, ataupun penyimpangan pengalokasian anggaran yang cenderung telah berorientasi pada kepentingan birokrasi dan bukan kepentingan masyarakat.

b. Pengungkapan

Dari hasil penelitian, laporan keuangan Sekretariat Daerah Kota Bengkulu telah menyajikan informasi yang lengkap mulai dari laporan realisasi anggaran, neraca, laporan arus kas, dan catatan atas laporan keuangan, dimana keseluruhan dari informasi tersebut disajikan secara jujur sesuai dengan standar akuntansi pemerintahan (SAP). Sehingga laporan keuangan Sekretariat Daerah Kota Bengkulu dapat diandalkan dan tidak akan meyesatkan.

c. Ketaatan Terhadap Peraturan Perundang-undangan

Berdasarkan penelitian yang dilakukan pengelolaan, penggunaan dan pelaporan keuangan Sekretariat Daerah Kota Bengkulu telah dilaksanakan sesuai dengan peraturan dan perundangan yang berlaku dalam hal ini yaitu Peraturan Pemerintah Nomor 71 Tahun 2010 tentang Standar Akuntansi Pemerintahan. Hal tersebut dapat dilihat dari laporan keuangan yang disusun dan disajikan telah mengungkapkan dengan jelas dan cukup mengenai semua 
hal yang menyangkut ketaatan terhadap peraturan dan perundangan yang ada, sehingga memiliki tingkat pertanggungjawaban yang memadai.

Dengan demikian, laporan keuangan yang dihasilkan oleh Sekretariat Daerah Kota Bengkulu menjadi transparan karena adanya pengungkapan hal yang material, pengungkapan yang berkala, dan kebebasan memperoleh informasi bagi masyarakat umum, Dewan Perwakilan Rakyat Daerah (DPRD), donatur, investor, dan kreditor. Selain itu, laporan keuangan Sekretariat Daerah Kota Bengkulu menjadi akuntabel karena adanya integritas keuangan yang berkaitan dengan kejujuran penyajian dalam arti informasi dalam laporan keuangan menggambarkan transaksi dan peristiwa yang seharusnya disajikan, pengungkapan lengkap dalam arti informasi dalam laporan keuangan disajikan selengkap-lengkapnya yang mungkin dapat mempengaruhi pengambilan keputusan, ketaatan terhadap peraturan perundang-undangan dalam arti pelaksanaan SAP sesuai dengan Peraturan Pemerintah Nomor 71 tahun 2010.

Hasil pengujian korelasi spearman rank membuktikan terdapat hubungan yang cukup antara Penerapan PP Nomor 71 tahun 2010 tentang Standar Akuntansi Pemerintah (SAP) dengan Akuntabilitas Kinerja Laporan Keuangan Sekretariat Daerah Kota Bengkulu.

\section{Kesimpulan}

Berdasarkan hasil penelitian pada Bagian Keuangan Sekretariat Daerah Kota Bengkulu, maka penulis mengambil kesimpulan sebagai berikut:

1. Hubungan penerapan Peraturan Pemerintah Nomor 71 tahun 2010 dengan akuntabilitas kinerja laporan leuangan pada Sekretariat daerah Kota Bengkulu. Berdasarkan hasil penelitian dengan metode analisis Spearman Rank menunjukan bahwa terdapat hubungan yang cukup kuat.

2. Pelaksanaan Standar Akuntansi Pemerintah pada Sekretariat Daerah Kota Bengkulu telah diterapkan dengan cukup baik, hal ini terbukti dari hasil kuesioner yang telah dilakukan dan juga terlihat dari adanya pencatatan, penggolongan, peringkasan dan pelaporan laporan keuangan yang meliputi laporan realisasi anggaran, laporan arus kas, neraca, dan catatan atas laporan keuangan yang telah disusun sesuai Peraturan Pemerintah Nomor 71 tahun 2010.

3. Pelaksanaan akuntabilitas kinerja laporan keuangan daerah pada Sekretariat Daerah Kota Bengkulu sudah berjalan dengan cukup baik, hal ini terbukti dari hasil kuesioner yang telah dilakukan dan juga terlihat dari adanya tiga komponen pokok yaitu: intergritas keuangan, pengungkapan laporan keuangan, serta ketaatan terhadap peraturan perundang-undangan yang diatur dalam Permendagri No.13 Tahun 2006.

\section{Saran}

Berdasarkan hasil penelitian atas penerapan Peraturan Pemerintah Nomor 71 tahun 2010 dengan akuntabiliatas kinerja laporan keuangan daerah pada Bagian Keuangan Sekretariat Daerah Kota Bengkulu, penulis merasa perlu untuk menambahkan beberapa saran dalam mengatasi kelemahan-kelemahan yang ada, yaitu :

1. Peneliti menyarankan agar pemahaman karyawan terhadap Standar Akuntansi Pemerintah ditingkatkan, salah satunya dengan cara adanya pengarahan dari kepala bagian kepada pegawai dalam pelaksanaan sistem akuntansi keuangan daerah agar pelaksanaan sistem akuntansi keuangan daerah pada Sekretariat Daerah Kota bengkulu yang sudah berjalan dengan sangat baik dapat dipertahankan.

2. Adanya pengawasan yang lebih ketat lagi dalam pelaksanaan akuntabilitas kinerja laporan keuangan daerah agar dalam pengungkapan laporan keuangan dapat membuat pemakai laporan keuangan paham dan tidak salah tafsir terhadap laporan keuangan yang disajikan oleh Sekretariat Daerah Kota Bengkulu.

3. Agar akuntabilitas laporan keuangan daerah dapat berjalan sesuai dengan peraturan perundang-undangan yang telah ditetapkan oleh pemerintah pusat, maka penerapan Peraturan Pemerintah Nomor 71 tahun 2010 tentang Standar Akuntansi Pemerintah juga 
harus lebih efektif lagi. Dan untuk peneliti selanjutnya yang ingin melakukan penelitian dengan topik yang sama, diharapkan dapat lebih intensif dalam melakukan penelitian mengenai faktor lain yang dapat mempengaruhi akuntabilitas kinerja laporan keuangan daerah seperti kebijakan pemerintah.

\section{DAFTAR PUSTAKA}

Anggawirya, Erhans, 2000. Sistem Akuntansi Berdasarkan Prinsip Akuntansi Indonesia, Edisi Pertama, PT. Ercontara Rajawali, Jakarta

Annisarahma. 2008. Akuntansi Sektor Publik Akuntansi Keuangan Daerah. Salemba Empat.

Bastian, Indra.2006. Akuntansi Sektor Publik :Suatu Pengantar. Jakarta: Penerbit Erlangga.

Halim, Abdul, 2004. Akuntansi Sektor Publik: Akuntansi Keuangan Daerah. Salemba Empat: Jakarta.

Keputusan Presiden Nomor 2 tahun 2005 Komite Standar Akuntansi Pemerintah. Jakarta

Oktarina, Heni. 2012. Peranan Laporan Akuntabilitas Kinerja Instansi Pemerintah Dalam Pengelolaan Anggaran Keuangan di Perwakilan BKKBN Provinsi Bengkulu. Bengkulu. UNIVED

Mahmudi. 2005. Manajemen Sektor Publik Edisi Revisi. UPP STIM YKPN: Yogyakarta.

Mahsun, Sulisyowati Firman dan Andre Purwanu Graha, Herbertus. 2007. Akuntansi Sektor Publik, Edisi Ke2: Penerbit BPFE Yogyakarta.

Peraturan Menteri Dalam Negeri No 13 Tahun 2006 Tentang Pedoman Pengelolaan Keuangan Daerah. Jakarta

Peraturan Menteri Dalam Negeri No 59 Tahun 2007 Tentang Perubahan Pedoman Pengelolaan Keuangan Daerah. Jakarta

Peraturan Menteri Dalam Negeri No 21 Tahun 2012 Tentang Perubahan Pedoman Pengelolaan Keuangan Daerah. Jakarta

Peraturan Pemerintah Nomor 24 tahun 2005 Tentang Standar Akuntansi Pemerintah. Jakarta

Peraturan Pemerintah Nomor 71 tahun 2010 Tentang Standar Akuntansi Pemerintah. Jakarta

Sari, Tina Fatma. 2012. Analisis Pencatatan dan Pelaporan Keuangan pada Sekretariat Daerah Propinsi Bengkulu . Bengkulu. UNIVED

Sugiyono. 2010. Metode Penelitian Bisnis. Bandung. Alfabeta.

Ulum, Ihyaul. 2004. Sebuah Pengantar Akuntansi Sektor Publik. UMM Press: Malang.

Undang-Undang Nomor 17 Tahun 2003 Tentang Keuangan Negara. Jakarta

Undang-Undang Nomor 32 Tahun 2004 Tentang Pemerintah Daerah. Jakarta

Undang-Undang Nomor 33Tahun 2004 Tentang Perimbangan Pemerintah Pusat dan Daerah. Jakarta 